\title{
The review of the book \\ "Employer Branding - Eine wissenschaftliche Analyse des State-of-the Art empirischer Untersuchung im Bereich Employer Branding" written by Peter Kuhn
}

\author{
Anna Jędrzejczyk \\ University of Warsaw \\ E-mail: anna.m.jedrzejczyk@student.uw.edu.pl \\ All rights reserved
}

Received: 16.10.2015 / Revised: 30.10.2015 / Accepted: 01.11. 2015 / Published online: 30.12 .2015

\begin{abstract}
This paper is a review of a book about employer branding written by Peter Kuhn. The comments and suggestions concerning its content are based on the literature available in English, German and Polish. Employer branding is very often analysed from the business point of view, but not so often from the linguistic one. The possible research fields are mentioned.
\end{abstract}

Keywords: employer branding, employment brand

This book is definitely a good start to analyse the phenomenon of employer branding. The author presents a summary of important aspects which could be taken into account in analysing this particular part of a company's management strategy. The book is divided into a couple of parts, namely: an introduction with an explanation of the methodology, characteristics of an attractive employer, influence of employer branding on employees and brand equity, a description of the ways of managing employer brand and criteria which could be taken into account in establishing the segmentation of the employee market. In each chapter the reader can find a summary of the most important key points in the topic and one research example described in more detail. The author is specialized in the marketing field, and that is why this work is also mostly a summary from the strategic business perspective.

Employer branding aims to create and manage the employer brand which appeals to internal "clients" such as employees and to "external" ones, for example job candidates and distributors. The author emphasizes that the term "employer branding" is quite new (Barrow, 1990); therefore, he tries to use the results of research from other fields which are directly or indirectly connected with employer branding in order to make some assumptions or draw conclusions. Some terms come from domains that are distant from employer branding, for example "child care", "centralization", "gender self-schema", but their indirect influence on the "company's reputation" or "corporate brand" is assumed to exist through deduction or some research results. The distinction between employer branding and corporate branding was not clearly shown in this state-of-the-art book. Instead, the author tries to find an influence of some company activities, such as CSR or the mentioned keywords, on attracting potential candidates. In scientific papers employer branding is often perceived as a process separate from the Corporate Social Responsibility, because the CSR 
main goal is to create a perception of ethical management and it is more the core of a company's reputation rather than creation of an image of being a good employer. CSR is a part of corporate branding that has an influence on employer branding, but this influence is indirect because, for an employee, the most important features of the employer brand are: the job itself, career chances, work environment and salary (Turban, 1993 and Ng/Burke, 2006). That is why, I would recommend to pay more attention to the aspects of employer branding which do have a direct impact on the reputation of a company as an employer, not as a company itself.

On the other hand, some important components of employer branding were unfortunately not mentioned, for example: discussion about employment brand vs. employer brand, the measurement of effectiveness of employer brand activities, corporate brand vs. product brand vs. employer brand, the statistics concerning the media usage in the employer branding management, and also the inconsistency between the perception of a company as an employer and the real image of this company. I would also recommend to mention which companies in which branches perceive employer branding as an important part of their management strategy (rankings of the best employers organized by Universum or other non-scientific companies).

One of the topics mentioned is the research about Person-Job Fit and Person-Organisation Fit (Carless, 2005) which takes into consideration two different perspectives of assessing an employer by a candidate who did not work for a particular company. The personality traits of potential candidates are compared with the characteristics of companies and it has come out that, also in those cases, correlations could be found. The author led the reader through different studies which have various hypotheses. In this part of the chapter it would be very advisable to present the concepts of employment brand and employer brand, especially when it was proved that P-J had a direct influence on the acceptance of the job offer by a candidate but was not an attractor factor. Job Fit is a reaction of a potential candidate to the job description (employment brand) which is presented in job offers. Organization Fit, on the other hand, is more connected with the perception of the employer brand as a part of the organization's image.

The aspect which was very well introduced in the reviewed book was the fact that different factors have an influence on the intentions to apply for a job and to quit it (Rad/De Moraes, 2009). Although the company characteristics such as the size of the company or the description of the company's services are the most often mentioned pieces of information in job descriptions (Backhaus, 2004), it was proved by some researches that these parts are the least important for the potential candidates. As the job description must always be mentioned in the job offer, companies must find other ways to distinguish themselves from other companies. Finding a competitive edge in the strategy of managing a realistic employment brand (job offer), instead of usually too general employer brand, is an important goal of a company's strategy. It seems that companies have standard forms of job offers which they use to find their candidates (Backhaus has created 10 such forms based on his statistical research connected with the keywords in the job offers posted on the monster.com). Meantime a Polish researcher (Lącka-Badura, 2012) has investigated the UK job offers and created a model employer branding advertisement which could be the same for every branch. Is the creation of a model job advertisement a clue in the business world? Peter Kuhn asked another question: How can companies distinguish their offer without forgetting about the factors which are the most important for candidates? In his book the author mentioned such company characteristics as: work-life balance, family concentrated company, flexible hours, corporate social responsibility, diversity management in order to show other aspects of companies' activities which could be unconventionally added to the job description. At this point, it should not be forgotten that unrealistic job offers that are too concentrated on the marketing concept of distinguishing themselves from those of other companies, which is often realized through employer branding, will be a way to attract candidates, but also a factor making those candidates resign from their job after gaining real experiences with the company (Phillips, 1998). An interesting fact is that the instrumental factors (i.e. pay, benefits, or the opportunities to travel 
abroad, etc.) were the factors which did not have such a big influence on the initial attractiveness of an employer (Lievens, Highhouse 2003). Symbolic meanings which correspond to non-productrelated attributes, especially user imagery (Keller, 1998), were perceived as decisive in this phase of analyzing job offers. However, when we differentiate the attractiveness of an employer as an employer brand from the actual decisions and decision criteria of accepting or not accepting a job offer, we can see that a candidate would pay attention to instrumental factors.

In this book the author concentrated on the strategic aspect of employer branding concerning the Employer Value Proposition, so on the values which could be offered by an employer. When we look closely at the operational aspects such as building the tools to transfer the knowledge about employer branding, we can see that there are more topics to discuss such as: the influence of job offers, of company events organized at universities, of video commercials, etc. Some research on those topic was also conducted, but was not a part of employer branding research. The author mentions some of those studies (for example, the influence of a company's website design on the corporate brand) as an example of a new field of research in management. The research about employer branding in the linguistic perspective concerning not only the text but also the multimodality of job offers or even the whole employer branding strategy is still based on the previous results of corporate brand research.

What should also be taken into account when writing this kind of state-of-the-art summaries is consistency in giving information about the researched group in all mentioned scientific results. As stated in the book, the expectations concerning employer branding vary depending on the gender, age and also the number of job offer alternatives which a candidate has. The cultural aspect was unfortunately not widely discussed although it has a significant role in defining the priorities in strategy creation (Christiaans, 2008). What is more, the branch or field in which potential candidates are searched for is also an important factor, because the so-called "war for talent" is stronger or weaker in some branches, which can have an influence on the research results. Those cultural, professional and social factors could have an influence on the research into employer branding.

This book is a summary which is strictly concentrated on the marketing point of the employer branding process. Employer branding is also connected with the human resources management, because the image of an employer brand should be coherent with the reality in order to prevent unnecessary rotation which could be caused by improper expectations. That is why in some research papers it is stated that employment brand should be differentiated from employer brand, because the first one corresponds more to operational goals of Human Resources where the employer brand is connected more with the corporate brand and creates the whole company image as a great place to work (Jędrzejczyk, 2013). The way of reconciling the world of marketing with the world of more human resources management is still a question. What to do to attract candidates but not create an unreal image of companies? It is also a topic which was mentioned in this book but not analyzed in detail. Generally speaking, it is a good summary of the employer branding literature if we concentrate only on the strategic marketing aspect of job offers.

\section{References}

Backhaus, K.B. (2004) An Exploration of Corporate Descriptions on Monster.com, Journal of Business Communication, 41(2), 115-134.

Backhaus, K.B. and Tikoo, S. (2004) Conceptualizing and researching employer branding, Career Development International, 9(5), 501-517.

Christiaans L. (2013) International Employer Brand Management: A Multilevel Analysis and Segmentation of Students' Preferences, Springer Science \& Business Media, Wiesbaden. 
Carless, S.A. (2005) Person-job fit versus person-organization fit as predictors of organizational attraction and job acceptance intentions: A longitudinal study, Journal of Occupational and Organizational Psychology, 78(3), 411-429.

Jędrzejczyk, A. (2013) Marka pracodawcy a marka zatrudnienia - dyskusja pojęć, in: Edukacja Ekonomistów i Menedżerów, no. 4, 131-140.

Lievens, F.and Highhouse, S. (2003) The relation of instrumental and symbolic attributes to a company's attractiveness as an employer, Personnel Psychology, 56(1), 75-102.

Łącka-Badura, J. (2013) Recruitment advertisement as an instrument of employer branding - a linguistic perspective, Uniwersytet Śląski.

Ng, E.S.W. and Burke, R.J. (2006) The next generation at work - business students' views, values and job search strategy. Education + Training, 48(7), 478-492

Turban, D.B. and Keon, T.L. (1993) Organizational attractiveness: An interactionist perspective, Journal of Applied Psychology, 78(2), 184-193.

Phillips, J.M. (1998) Effects of realistic job previews on multiple organizational outcomes: A meta-analysis. Academy of Management Journal, 41(6), 673-690. 